\title{
Different methods of assessing writing among EFL teachers in Iran
}

Ketabi, Somaye $\bowtie$

Department of Foreign Languages, University of Isfahan, Iran (s86k@hotmail.com)

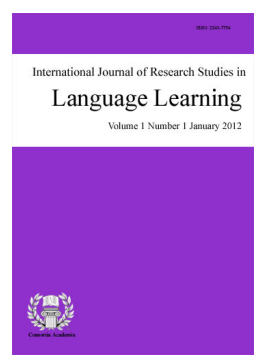

ISSN: 2243-7754 Online ISSN: 2243-7762

OPEN ACCESS

\section{Abstract}

Although investigating the effectiveness of different methods of assessing writing in EFL classes has been one of the main objectives among researchers in Iran (Elahinia, 2004; Nezakatgoo, 2005; Javaherbakhsh, 2010), examining the popularity of these methods has never gained this much attention. This article examines the frequency of methods of assessing writing among teachers of adult and young adult learners in Iran and also investigates the difference in the frequency of the methods used by two groups of teachers. The category of different methods was chosen by the help of Brown's (2004) classification and also the study conducted by Cheng, Rogers, \& Hu (2004). The data were gathered by using questionnaires. The results revealed that the most common methods to assess writing were writing essays and dictation among teachers of adult and young adult learners respectively. Alternative assessment methods (e.g. journals, portfolios, and peer/self-assessment) were the least common methods. This finding was somehow paradoxical to the results found by other researchers who showed that portfolios, journals, and other methods of alternative assessment could be effective in improving student writing skill.

Keywords: English as Foreign Language; assessment; alternative assessment; writing; methods of assessing writing 


\section{Different methods of assessing writing among EFL teachers in Iran}

\section{Introduction}

\subsection{Different views towards writing}

Writing has an especial status in people's mind since it is the skill by which several messages can be transferred to different readers - known or unknown; a close friend or a stranger. In educational settings, writing is more valued than speaking for its standardized nature, so fluency in writing is considered more important than fluency in speaking (Weigle, 2002). This skill produces less communicative pressure comparing with speaking (Grabowski, 1996), but lack of immediate feedback puts cognitive load because the writer should anticipate readers' feedback while shaping the topic and outline of the text (Weigle, 2002). Moreover, students should be able to write in different genres. As Reppen (2002) strongly claims, writing is a necessary skill for L1 learners and a fundamental requirement for L2 learners.

Traditional models of writing focused on cognitive aspect and did not consider the cultural and social nature of this skill. Responding to literary texts was the focus in teaching writing to native English speakers in mid-1960s. Teaching rules and principles of text organizations was the standard at that time. Discussion about a text and writing assignments were also among the routines in writing classes. This product-oriented approach was criticized after introducing think-aloud technique by Janet Emig in the late 1960s (Kroll, 1990). She observed that writers did not follow the linear procedures as was dictated in traditional models. Cyclical approach defines writing process more accurately than linear approach. Therefore, "focus on the form" was changed to "focus on the writer" in process-oriented approach. Scholars and teachers started to view writing as "an act that takes place within a context, that accomplishes a particular purpose, and is appropriately shaped for its intended audience" (Hamp-Lyons \& Kroll, 1997, p.8). So, the social and cultural aspects of writing were then taken into consideration.

\subsection{Assessing writing}

In assessing writing, like assessing other skills, first the objectives should be identified and then the tasks should be designed based on the objectives.

Brown (2004) has classified writing types based on some general objectives:

$>$ Imitative: Basic tasks of writing alphabet, words, and very short sentences are some types of imitative writing tasks.

$>\quad$ Intensive (controlled): Writing correct words in context and correct grammatical features in sentence writing are two important elements in controlled writing. Form is much more important than meaning and context.

$>$ Responsive: In this type of writing the writer has learnt about sentence-level grammar and is more concerned about discourse. Form is important at discourse level and meaning and context are emphasized. Brief descriptions, short reports, summaries, and interpretation of charts and graphs are examples of responsive writing tasks.

$>$ Extensive: In extensive writing, writers focus on achieving a purpose through organizing ideas logically and employing varieties of syntactic and lexical forms. Writing theses and term-papers are some possible tasks in extensive writing category. 
Imitative writing tasks - All around the world English learners start learning to write in English at the beginning level of their education. This type of learning is fundamental to learn other types of writing. Copying, listening cloze selection tasks, picture-cued tasks, form completion tasks, and converting numbers and abbreviations to words are some examples of tasks in imitative writing category. In copying task the learner should read the word and copy it in the correct order. This process is changed into a paragraph in listening cloze task. The learner reads a paragraph, and then s/he should complete the same paragraph in which some words are deleted (Brown, 2004). In picture-cued tasks some pictures are displayed and the learner should choose related words. An alternative to this task is form completion task in which the learner should write her/his name or address. Sometimes test-designers use items with numbers and abbreviations in them, and test-takers should produce the numbers in words or the complete vocabulary for that abbreviation (Ibid).

Intensive (controlled) writing tasks - Form-focused, guided writing, and grammar writing are other names of intensive writing. Most of writing is display rather than real in intensive writing (Brown, 2004). Attending to form is much more important than meaning. There is no information transfer in this type of writing and correct combining of words are in focus. Dictation or dicto-comp, grammatical transformation tasks, picture-cued tasks, ordering, and short-answer and sentence completion tasks are some examples of controlled writing tasks (Ibid). In dicto-comp the teacher reads a text two or three times and the students should reproduce it in written form. In another task, grammar transformation task, students should change the tense of a paragraph or change the statements into negative or yes/no questions. In picture-cued tasks, students see a picture and write sentences based on the pictures.

Responsive and extensive writing tasks - Based on complexity of the open-ended and meaningful tasks, they can be either responsive or extensive. Paraphrasing, guided question and answer, paragraph construction, reports, summaries, narrations, and descriptions are examples of responsive and extensive tasks.

\subsection{Alternative assessment}

Long traditional paper-and-pencil tests have always been so stressful to students. Any kind of test which lacks further feedback and which is viewed only as a tool by which teachers can gather scores can be demanding even if teachers have primarily designed the test to facilitate learning and teaching. Traditional summative assessments aim at providing a written document by forgetting about the process involved in answering the questions. This high attention to the results makes teachers teach to the test and force the students to exercise the same drills several times. This is a major obstacle on the way of developing creativity and authenticity in language use. Moreover, summative assessment lacks further diagnostic information and students usually do not about their weak points after taking part in an achievement test (a kind of summative assessment). Dissatisfaction of traditional formal tests resulted in developing a new kind of assessment called alternative assessment. The main focus of this newly developed assessment was to add more tools to measure students' abilities. Brown and Hudson (1998, pp. 654-655) label these new tools "alternatives in assessment" which require students to perform; use real-world tasks; are every-day classroom activities; assess students' "true" abilities in normal condition; focus on process and product; employ thinking and problem-solving skills; provide information about strong and weak points of the students. Some examples of alternative assessment tasks are described in the following sections.

Portfolios - Portfolios assess learners' achievement over a period of time. Genesee and Upsher (1996) defined a portfolio as "a purposeful collection of student's work that demonstrates their efforts, progress, and achievements in a given area" (p. 99). Portfolios can be essays, reports, creative prose, photos, diaries, written homework exercises, and the like. As Brown (2004) stated, "a journal is a log (or 'account') of one's thoughts, feelings, reactions, assessments, ideas, or progress toward goals, usually written with little attention to structure, form, or correctness" (p. 260). Most of classroom journals are dialogue journals which consist of interactions between the teacher and the learner. Responses to journals should be provided during the course. Journals provide valuable information about students' learning progress. 
Ketabi, S.

Self- and peer-assessment - Autonomy and cooperative learning are basic principles of self- and peer-assessment. Autonomy can lead learning progress to success by making the students set their own goals, pursue them without pressure of teachers, and also monitor their progress continuously (Brown, 2004). Self-assessment can foster intrinsic motivation. Cooperative learning, on the other hand, appreciates collaboration and the benefits of a community of learners. Peer-assessment is an example of tasks in learner-centered education (Ibid).

\subsection{Cheng, Rogers, \& Hu's study (2004)}

Their study carried out a comprehensive study on classroom assessment purposes, methods, and procedures in three settings of Canada, Beijing, and Hong Kong. Their work inspired the present study. These researchers suggested that less was known about classroom assessment of EFL/ESL instructors. This issue would become more essential if large number of students, influence of formal testing, and central role of this kind of assessment in learning and teaching processes were considered (Cheng, Rogers, \& Hu, 2004). University teachers in different language settings (English dominant, bilingual, and Mandarin-dominant) were chosen by purposive sampling. The findings revealed that assessment is highly context-dependent and nature of the courses, teaching experience of instructors, levels of students, and the role of external testing can have significant effects on classroom assessment. Teachers in Cheng et al.'s study were more inclined to use teacher-made tests to assess reading. Writing summary was also among popular methods to assess reading in three countries. Moreover, teachers were reported that they used essays to assess writing more than other methods. Canadian teachers employed more learner-centered methods (e.g. journals and portfolios) in their classes. About half of the teachers in Hong Kong chose peer-assessment and portfolios as common methods to assess writing. In order to assess speaking and listening, teachers in Canada and Hong Kong chose performance methods as the most popular ones. On the other hand, teachers in Beijing were more inclined to use standardized tests.

\subsection{Assessing writing in Iranian EFL classes}

Examining different methods of assessing writing is limited to alternative assessment methods in Iran and they have been the focus of attention among Iranian EFL researchers in recent years. Many studies have focused on the effect of using portfolios, peer/self-assessment, and journals on improving students' writing skill (Elahinia, 2004; Nezakatgoo, 2005; Javaherbakhsh, 2010; Ghorchaei, Tavakoli, \& Nejad Ansari, 2010; Moradan \& Hedayati, 2011; Sharifi \& Hassaskhah, 2011; Mosmery \& Barzegar, 2015). It can be said that all of these studies indicate that alternative assessment methods have a significant effect on improving students' writing skill.

Elahinia (2004) revealed significant contribution of portfolio assessment in improving students' writing proficiency in a quasi-experimental design. She also showed that students had a positive attitude towards portfolio assessment. In another quasi-experimental design, Nezakatgoo (2005) concluded that portfolio-based assessment had a significant effect on improving students' writing skill. In Javaherbakhsh (2010), the effect of using self-assessment techniques in improving writing was significant in comparison with a group who received traditional methods. Ghorchaei et al. (2010) also revealed that portfolio assessment had a significant effect on improving students' writing in the areas of focus, vocabulary, elaboration, and organization. Moreover, Moradan and Hedayati (2011) showed that intermediate students who received conferencing and portfolio-based assessment performed significantly better than those who received scores without any further feedback. Sharifi and Hassaskhah (2011) and Mosmery and Barzegar (2015) were among other researchers who found that portfolios and self-assessment are effective ways to help students write better assignments. However, investigating the popularity of these methods and also other methods of assessing writing has not been the focus among Iranian EFL researchers.

\subsection{Overview of the present study}

Although studying the effect of alternative assessment methods was the objective in many studies in Iran, 
investigating other methods of assessing writing among EFL teachers did not gain much attention. So, the researcher in this study focused on understanding the most popular methods to assess writing in Iran EFL classrooms. Moreover, two groups of teachers (teachers of adult and young adult learners) were investigated in order to achieve comprehensive results. The data were gathered by using questionnaires and differences between two groups of teachers were then explored.

\section{Methodology}

\subsection{Research questions and hypotheses}

This study was conducted to find plausible answers to the following questions:

$>\quad$ What are the most common methods to assess writing in Iranian EFL adult and young adult learners' classes?

$>\quad$ Is there any significant difference between methods of assessing writing employed by teachers in Iranian EFL adult and young adult learners' classes?

One null hypothesis was formed according to the last question:

$\left.>\mathrm{H}_{0} 1\right)$ There is no significant difference between the method of assessing writing used by teachers in Iranian EFL adult and young adult learners' classroom.

\subsection{Research design}

The present study is a descriptive and comparative study. It is descriptive since it tries to describe the methods of assessing writing in Iranian EFL classes, and it is comparative as it presents a comparison of assessment methods used in adult and young adult classes.

\subsection{Participants}

Ten institutes (in Isfahan) were chosen randomly (simple random sampling). However, not all the teachers in randomly selected institutes agreed to fill out the questionnaire. Accidental sampling was employed to choose the individuals. 200 male and female teachers filled out the questionnaire; however, 150 questionnaires were used since 50 questionnaires were filled incorrectly.

\section{Table 1}

Characteristics of the participants (part 1)

\begin{tabular}{lcccc}
\hline \multicolumn{1}{c}{ Characteristics of teachers } & Min. & Max. & Mean & $\mathrm{N}$ \\
\hline Age (all the teachers) & 20.00 & 53.00 & 27.2800 & 150 \\
\hline Adult learners' teachers & 22 & 50 & 27.5333 & 75 \\
Young adult learners' teachers & 20 & 53 & 27.0267 & 75 \\
\hline Experience & 1.00 & 17.00 & 5.2467 & 150 \\
\hline Adult learners' teachers & 1 & 17 & 6.0267 & 75 \\
Young adult learners' teachers & 1 & 16 & 4.4667 & 75 \\
\hline Number of classes in a week & 1.00 & 15.00 & 4.9467 & 150 \\
\hline Adult learners' teachers & 1 & 14 & 5.1600 & 75 \\
Young adult learners' teachers & 1 & 15 & 4.7333 & 75 \\
\hline Average number of students in one class & 4.00 & 30.00 & 12.3333 & 150 \\
\hline Adult learners' teachers & 4 & 30 & 11.6533 & 75 \\
Young adult learners' teachers & 4 & 30 & 13.0133 & 75 \\
\hline
\end{tabular}

Among these teachers, 75 teachers were teaching to young adults (students who are 12-18 years old) and 75 teachers were teaching to adults (students who were 18-30). They had different years of experience (1 year to 17 
Ketabi, S.

years of experience) and aged between 20 and 53. Moreover, number of classes ranged between 1 and 17 classes in a week, and number of students in each class were between 4 and 30 students. Table 1 presents teachers' age, experience, number of classes in a week, and an average number of students they have in one class.

Table 2

Characteristics of the participants (part 2)

\begin{tabular}{|c|c|c|c|c|c|c|}
\hline \multirow[t]{2}{*}{ Characteristics of teachers } & \multicolumn{2}{|c|}{ Adults } & \multicolumn{2}{|c|}{ Young adults } & \multicolumn{2}{|c|}{ Total } \\
\hline & $\mathrm{N}$ & $\%$ & $\mathrm{~N}$ & $\%$ & $\mathrm{~N}$ & $\%$ \\
\hline \multicolumn{7}{|l|}{ Gender } \\
\hline Female & 48 & 64 & 53 & 70.7 & 101 & 67.3 \\
\hline Male & 27 & 36 & 22 & 29.3 & 49 & 32.7 \\
\hline \multicolumn{7}{|l|}{ Educational degree } \\
\hline $\mathrm{BA}$ & 24 & 32 & 30 & 40 & 54 & 36 \\
\hline MA & 47 & 62.7 & 45 & 60 & 92 & 61.3 \\
\hline $\mathrm{PhD}$ & 4 & 5.3 & 0 & 0 & 4 & 2.7 \\
\hline \multicolumn{7}{|l|}{ Level of the students } \\
\hline Beginners & 11 & 14.7 & 31 & 41.3 & 42 & 28 \\
\hline Intermediate & 32 & 42.7 & 40 & 53.3 & 72 & 48 \\
\hline Advance & 32 & 42.7 & 4 & 5.3 & 36 & 24 \\
\hline \multicolumn{7}{|c|}{ Participation in teacher training course or workshop } \\
\hline Yes & 64 & 85.3 & 60 & 80 & 124 & 82.7 \\
\hline No & 11 & 14.7 & 15 & 20 & 26 & 17.3 \\
\hline \multicolumn{7}{|c|}{$\begin{array}{c}\text { Participation in language assessment course or } \\
\text { workshop }\end{array}$} \\
\hline Yes & 61 & 81.3 & 66 & 88 & 127 & 84.7 \\
\hline No & 14 & 18.7 & 9 & 12 & 23 & 15.3 \\
\hline
\end{tabular}

Female teachers were more than male teachers in this study: 101 teachers were female and 49 teachers were male. Most of the participants had MA in English (all the participants were students of TEFL, English translation, or English literature), and most of them were teaching students at intermediate or advanced level. Out of 150 teachers, 26 teachers had not participated in a teacher training course or workshop, and 23 teachers had not taken part in a language assessment course or workshop. Table 2 provides a better illustration of teachers' gender, educational degree, level of the students they teach, and their participation in teaching or assessment workshops or courses.

\subsection{Instruments}

Two types of questionnaire were used in order to collect data for the present study. These questionnaires were used to know about teachers' background information and specific methods they use to assess writing in their classes.

Background Information Questionnaire - This questionnaire consisted of some items asking about teachers' gender, age, major of study, participation in courses of teacher training and assessment, teaching experience, hours of teaching per week, levels of their students (basic, intermediate, advance), and average number of students in each class. In addition, it was indicated that the study was conducted in order to understand differences in formative assessment's purposes, methods, and procedure in adult and young adult learners' classes, and teachers should consider one group in filling out the questionnaire. This BIQ questionnaire was written in English.

Assessment questionnaire - The assessment questionnaire was partly based on Cheng et al.'s (2004) study which was about methods of assessing different skills. The methods were listed by the help of different studies and books about assessing skills. In addition, the researcher in this study organized the methods based on Brown's (2004) classification of different types of writing. Five-point Likert scale was provided for this part of the questionnaire. The method part was in English, since, after conducting the pilot study, it was concluded that 
teachers were more familiar with English names of different methods. Ten methods were mentioned to assess writing. Additionally, a separate part was provided for teacher-made tests which consisted of six items. The categorization of methods to assess writing is shown in Table 3.

Table 3

Categorization of writing tasks in this study

\begin{tabular}{lll}
\hline 1 & $\begin{array}{l}\text { Imitative-intensive tasks } \\
\text { Tasks which aim at fundamental skills of writing }\end{array}$ & Dictation \\
\hline 2 & $\begin{array}{l}\text { Responsive } \\
\text { Students work at discourse level and they focus } \\
\text { more on meaning }\end{array}$ & Prepare written summaries of what is read \\
& Written description of an event or object \\
\hline 3 & Extensive tasks & \\
& Students can succesffully manage processes and \\
strategies of writing. & Writing essays \\
\hline 4 & Alternatives in assessment & \\
& & Student journal \\
& & Student portfolio \\
& Peer assessment \\
\hline 5 & Teacher-made tests & Self-assessment \\
& Paper-and-pencil tests designed, administered, & Multiple-choice items to identify grammatical errors in \\
& and scored by teachers & a sentence \\
& & True-false items \\
& & Matching items \\
& & Short answer items \\
& & Sentence completion items \\
\hline 6 & Standardized writing tests & \\
\hline
\end{tabular}

\subsection{Pilot study}

The main reason for conducting the pilot study was to determine the validity and reliability of the questionnaire. Any vague or confusing items reported by teachers would be revised or deleted in the main study. Thirty teachers were asked to fill out the questionnaires and write their comments in English or Persian. Some items were ambiguous based on teachers' comments. So, the researcher provided comprehensible definitions for them. Some items were reported to be never used by Iranian teachers, so they were deleted. The language of two questionnaires was considered appropriate by teachers. Those who participated in the pilot study were not allowed to take part in the main study.

The amount of time required to fill out the questionnaire was determined in the pilot study, too. According to teachers' answers, 4-6 minutes were enough to complete the questionnaire. After analyzing the items with SPSS software, the Cronbach's alpha of the assessment questionnaire was determined to be 0.905 .

\subsection{Data collection procedure}

Data were collected in two months. One month before the main study the pilot study was done and the questionnaire was revised. After the pilot study, the researcher went to 10 private English institutes which were selected randomly, and explained the instructions for teachers. The questionnaires were then distributed. Some questionnaires were not completed correctly, so they were returned to teachers or were omitted. Gathering the data in this phase was done during one month in which the researcher could collect 75 questionnaires from adult learners' teachers and 75 questionnaires from young adult learners' teachers.

\subsection{Data analysis procedure}

At first, descriptive statistics was employed by the help of SPSS 16.0 software to understand which methods of writing were common among the teachers of adult and young adult learners. As Likert scale was used, total 
Ketabi, S.

score was calculated for each item in in order to understand the most common methods. Based on the nature of the data and scale which was ordinal, non-parametric statistics was employed to compare the methods of assessing writing in adults' and young adults' classes. Chi-square test was chosen to see whether a significant difference existed between two groups.

\section{Data Analysis and Results}

The first research question was formulated to know about different methods used by Iranian teachers to assess writing. Participants in this study completed the assessment questionnaire by using different numbers which actually indicated how often they used each method. In order to understand which methods were the most popular, the researcher calculated the score for each item.

\subsection{Popularity of different methods to assess writing}

Item scores were calculated to understand which methods were the most famous among Iranian teachers. Since some categories of writing assessment methods include two or more types of methods, average score was calculated. Table 4 summarizes the results of this part of the study.

\section{Table 4}

Total scores of methods of assessing writing

\begin{tabular}{llc}
\hline \multicolumn{1}{c}{ Categories of writing assessment methods } & $\begin{array}{c}\text { Total scores of each category used by teachers } \\
\text { of adult lyoung adult learners }\end{array}$ \\
\hline 1 & $\begin{array}{l}\text { Imitative-intensive tasks } \\
\text { Dictation }\end{array}$ & $202 \backslash 282$ \\
\hline 2 & $\begin{array}{l}\text { Responsive tasks } \\
\text { Prepare written summaries of what is read }\end{array}$ & $206 \backslash 180.5$ \\
& Written description of an event or object & \\
\hline 3 & Extensive tasks & \\
& Writing essays & \\
\hline 4 & Alternative assessment tasks & \\
& Student journal & \\
& Student portfolio & \\
& Peer assessment & \\
& Self-assessment & $164.5 \backslash 151.5$ \\
\hline 5 & Teacher-made tests & $179 \backslash 210$ \\
\hline 6 & Standardized writing tests \\
\hline
\end{tabular}

The most frequent method of assessing writing was extensive task of writing essay among teachers of adult learners. This method was popular among teachers of young adult learners likewise, as it was the second mostly reported method by them. The second most popular task among teachers of adult learners was teacher-made tests. The most frequently used method among teachers of young adult learners was reported to be imitative-intensive task of dictation. Alternative assessment methods were the least reported methods of assessing writing.

Imitative-intensive writing tasks - Dictation is a task that can be used at both level of imitative and intensive. This task was the most common task among teachers of young adult learners as 64 teachers in this group reported that they often or always made use of this task. In contrast, teachers of adult learners did not prefer this task, since 36 percent of them reported that they often or always made use of dictation to assess writing. Moreover, more than half of the teachers in adult learners' classes never or rarely employed this method. Teachers of young adult learners used dictation significantly more than teachers of adult learners as Assymp Sig. is less than 0.5. Table 5 shows the frequency of this method among teachers of both groups. 
Table 5

Frequency of imitative-intensive writing task

\begin{tabular}{|c|c|c|c|c|c|c|c|c|}
\hline \multirow{2}{*}{\multicolumn{2}{|c|}{ Imitative-intensive task }} & \multicolumn{6}{|c|}{ adultslyoung adults' teachers } & \multirow[b]{2}{*}{$\begin{array}{l}\dot{\infty} \\
\dot{n} \\
\dot{\vec{Z}} \\
\text { 荌 }\end{array}$} \\
\hline & & $\begin{array}{l}\overline{0} \\
\overrightarrow{0} \\
\overline{0}\end{array}$ & 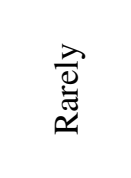 & $\begin{array}{l}\mathscr{Q} \\
\stackrel{\Xi}{0} \\
\mathscr{0} \\
\tilde{\Omega}\end{array}$ & $\underbrace{ \pm}_{0}$ & $\frac{\infty}{2}$ & $\begin{array}{c}\text { Total } \\
\text { score of } \\
\text { the item }\end{array}$ & \\
\hline \multirow{2}{*}{ Dictation } & $\mathrm{N}$ & $27 \backslash 10$ & $13 \backslash 7$ & $8 \backslash 10$ & $10 \backslash 12$ & $17 \backslash 36$ & \multirow{2}{*}{2021282} & \multirow{2}{*}{$.002 *$} \\
\hline & $\%$ & $36 \backslash 13.3$ & $17.3 \backslash 9.3$ & $10.7 \backslash 13.3$ & $13.3 \backslash 16$ & $22.7 \backslash 48$ & & \\
\hline
\end{tabular}

Note. No. of teachers in each group: $75 ; * p<0.05$

Responsive writing tasks - Asking students to provide written summaries of what is read and written description of an object or event are two responsive tasks of writing in which students have freedom of choice and should concentrate on context and meaning. These tasks ranked $3^{\text {rd }}$ and $5^{\text {th }}$ among teachers of adult and young adult learners respectively. As it is indicated in Table 6, written description was more common than summaries of what is read among teachers in both groups. More than 45 percent of teachers of adult and young adult learners reported that they always or often asked students to prepare written descriptions; however, just about 15 percent of them often or always employed written summaries to assess writing. Nevertheless, percentage of young adult learners' teachers who rarely or never employed written summaries was significantly more than number of teachers of adult learners who did so.

Table 6

Frequency of responsive writing tasks

\begin{tabular}{|c|c|c|c|c|c|c|c|c|}
\hline \multirow[b]{2}{*}{ Responsive tasks } & \multicolumn{7}{|c|}{ adultslyoung adults' teachers } & \multirow[b]{2}{*}{$\begin{array}{l}\dot{\infty} \\
\dot{n} \\
\dot{0} \\
\dot{\vec{n}}\end{array}$} \\
\hline & & $\begin{array}{l}\dot{0} \\
\overrightarrow{0} \\
\bar{z}\end{array}$ & 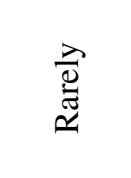 & 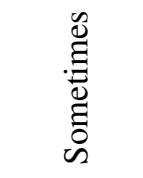 & $\underbrace{\frac{\Xi}{0}}_{0}$ & $\frac{\sum_{i}^{\infty}}{\pi}$ & $\begin{array}{l}\text { Total } \\
\text { score of } \\
\text { the item }\end{array}$ & \\
\hline \multirow{2}{*}{$\begin{array}{l}\text { Prepare written } \\
\text { summaries of what } \\
\text { is read }\end{array}$} & $\mathrm{N}$ & $40 \backslash 53$ & $5 \backslash 9$ & $20 \backslash 1$ & $3 \backslash 7$ & $7 \backslash 5$ & \multirow{2}{*}{$157 \backslash 127$} & \multirow{2}{*}{$.000^{*}$} \\
\hline & $\%$ & $53.3 \backslash 70.7$ & $6.7 \backslash 12$ & $26.7 \backslash 1.3$ & $4 \backslash 9.3$ & $9.3 \backslash 6.7$ & & \\
\hline \multirow{2}{*}{$\begin{array}{l}\text { Prepare written } \\
\text { description of an } \\
\text { object or event }\end{array}$} & $\mathrm{N}$ & $13 \backslash 17$ & $8 \backslash 12$ & $15 \backslash 11$ & $14 \backslash 15$ & $25 \backslash 20$ & \multirow{2}{*}{$255 \backslash 234$} & \multirow{2}{*}{.109} \\
\hline & $\%$ & $17.33 \backslash 22.6$ & $10.6 \backslash 16$ & $20 \backslash 16.07$ & $18.6 \backslash 20$ & $33.3 \backslash 26.6$ & & \\
\hline
\end{tabular}

Note. No. of teachers in each group: $75 ;{ }^{*} p<0.05$

Extensive writing tasks - Extensive writing tasks were indicated as popular tasks by teachers of adult and young adult learners. They were the most and the second popular methods of assessing writing among teachers of adult and young adult learners respectively. The results show that about 60 percent of adult learners' teachers employed essays to assess writing, whereas 48 percent of young adult learners' teachers did so. The difference, however, is not significant since $\mathrm{p}$ value is not less than or equal to 0.05 (see Table 7).

Table 7

Frequency of extensive writing task

\begin{tabular}{|c|c|c|c|c|c|c|c|c|}
\hline \multirow[b]{2}{*}{ Extensive task } & & \multicolumn{6}{|c|}{ adultslyoung adults' teachers } & \multirow[b]{2}{*}{$\begin{array}{l}\dot{\infty} \\
\dot{0} \\
\dot{0} \\
\dot{8} \\
\dot{0}\end{array}$} \\
\hline & & $\begin{array}{l}\dot{0} \\
\overrightarrow{0} \\
z\end{array}$ & 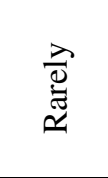 & 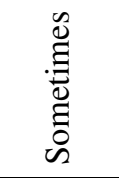 & $\underbrace{ \pm}_{0}$ & $\sum_{\substack{3 \\
\frac{1}{2}}}^{\infty}$ & $\begin{array}{l}\text { Total } \\
\text { score of } \\
\text { the item }\end{array}$ & \\
\hline \multirow{2}{*}{ Writing essay } & 75 & $8 \backslash 15$ & $5 \backslash 12$ & $17 \backslash 12$ & $16 \backslash 13$ & $29 \backslash 23$ & \multirow{2}{*}{$278 \backslash 242$} & \multirow{2}{*}{.143} \\
\hline & $\%$ & $10.7 \backslash 20$ & $6.7 \backslash 16$ & $22.7 \backslash 16$ & $21.3 \backslash 17.3$ & $38.7 \backslash 30.7$ & & \\
\hline
\end{tabular}

Note. No. of teachers in each group: $75 ; * p<0.05$ 
Ketabi, S.

Alternative assessment writing tasks - Asking students to keep journals and making portfolios of their works were two of the least popular tasks among teachers in this study. As with students' journals, about 19 percent of teachers in both groups reported that they employed this method. Almost the same percentage of teachers (21 and 18.6 percent of teachers in adult and young adult learners' classes in turn) employed portfolios to assess writing skill. As a matter of fact, when the researcher was distributing the questionnaires, most of the teachers indicated that they did not know about these methods. In addition, more than 60 percent of teachers in each group reported that they never or rarely employed self- or peer-assessment. There is no significant difference in employing alternative methods of assessment except for student portfolios. Teachers of adult learners made use of this method significantly more than teachers of young adult learners.

Table 8

Frequency of alternative assessment writing tasks

\begin{tabular}{|c|c|c|c|c|c|c|c|c|}
\hline \multirow{2}{*}{\multicolumn{2}{|c|}{$\begin{array}{c}\text { Alternative assessment } \\
\text { tasks }\end{array}$}} & \multicolumn{6}{|c|}{ adultslyoung adults' teachers } & \multirow[b]{2}{*}{$\begin{array}{l}\dot{00} \\
\dot{2} \\
\dot{0} \\
\dot{8}\end{array}$} \\
\hline & & $\begin{array}{l}\dot{\bar{D}} \\
\dot{0} \\
z\end{array}$ & $\begin{array}{l}\vec{d} \\
\stackrel{\vec{\Xi}}{\simeq}\end{array}$ & 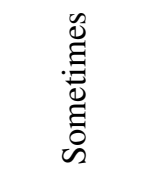 & $\underbrace{\frac{\Phi}{2}}_{0}$ & $\sum_{i}^{\infty}$ & $\begin{array}{c}\text { Total } \\
\text { score of } \\
\text { the item }\end{array}$ & \\
\hline \multirow{2}{*}{ Student journal } & $\mathrm{N}$ & $39 \backslash 46$ & 818 & $14 \backslash 7$ & $10 \backslash 10$ & $4 \backslash 4$ & \multirow{2}{*}{$157 \backslash 143$} & \multirow{2}{*}{.573} \\
\hline & $\%$ & $52 \backslash 61.3$ & $10.7 \backslash 10.7$ & $18.7 \backslash 9.3$ & $13.3 \backslash 13.3$ & $5.3 \backslash 5.3$ & & \\
\hline \multirow{2}{*}{ Student portfolio } & $\mathrm{N}$ & $37 \backslash 44$ & $8 \backslash 14$ & $14 \backslash 7$ & $13 \backslash 10$ & $3 \backslash 4$ & \multirow{2}{*}{$162 \backslash 140$} & \multirow{2}{*}{$.049 *$} \\
\hline & $\%$ & $49.3 \backslash 58.7$ & $10.7 \backslash 18.7$ & $18.7 \backslash 4$ & $17.3 \backslash 14.7$ & $4 \backslash 4$ & & \\
\hline \multirow[b]{2}{*}{ Peer assessment } & $\mathrm{N}$ & $40 \backslash 43$ & 418 & $11 \backslash 9$ & $12 \backslash 4$ & $8 \backslash 11$ & \multirow[b]{2}{*}{$169 \backslash 157$} & \multirow[b]{2}{*}{.191} \\
\hline & $\%$ & $53.3 \backslash 57.3$ & $5.3 \backslash 10.7$ & $14.7 \backslash 12$ & $16 \backslash 5.3$ & $\begin{array}{c}10.7 \backslash 14 . \\
7\end{array}$ & & \\
\hline \multirow{2}{*}{ Self-assessment } & $\mathrm{N}$ & $42 \backslash 41$ & 419 & $10 \backslash 10$ & $10 \backslash 8$ & $9 \backslash 7$ & \multirow{2}{*}{$165 \backslash 456$} & \multirow{2}{*}{.230} \\
\hline & $\%$ & $56 \backslash 54.66$ & $5.3 \backslash 12$ & $13.3 \backslash 13.3$ & $13.3 \backslash 10.6$ & $12 \backslash 9.33$ & & \\
\hline
\end{tabular}

Teacher-made writing tests - Among 150 teachers of adult and young adult learners, 56 teachers in each group reported that they rarely, sometimes, often, or always made use of their own tests to assess writing skill in their classes. This method of assessing writing was reported to be significantly more popular among teachers of adult learners as Asymp. Sig. and total scores indicates (see Table 9). Among different types of tests, editing, sentence completion items, and short answer items were the most common tasks among teachers of both groups.

Teachers of both groups did not differ significantly in employing different types of teacher-made tests except for editing. Teachers of adult learners employed editing significantly more than teachers of young adult learners.

Standardized writing tests - Standardized writing tests were significantly more popular among teachers of young adult learners than they were among teachers of adult learners as p value is less than 0.05 (Asymp. Sig. $=.009$ ). More than 40 percent of young adult learners' teachers often or always used this method while 22 percent of adult learners' teachers did the same. In point of fact, standardized tests were the third frequent method of assessing writing among teachers of young adult learners. Table 10 shows the frequency of this method among teachers of both groups.

Among all the methods listed in the questionnaire of this study, two methods -dictation and writing essayswere often and always used by many teachers while other methods were not this much popular. So, it can be concluded that teachers in this study did not use varieties of methods to assess writing skills. Moreover, alternative assessment methods and self- and peer assessment were reported to be infrequently used by teachers of adult and young adult learners. 


\section{Table 9}

Frequency of teacher-made writing tests and different types of teacher-made tests

\begin{tabular}{|c|c|c|c|c|c|c|c|c|}
\hline \multirow[b]{2}{*}{$\begin{array}{l}\text { Teacher-made tests to assess } \\
\text { writing }\end{array}$} & \multicolumn{7}{|c|}{ adultslyoung adults' teachers } & \multirow[b]{2}{*}{$\begin{array}{l}\dot{\infty} \\
\dot{n} \\
\dot{2} \\
\text { 离 }\end{array}$} \\
\hline & $\mathrm{N}$ & $\begin{array}{l}\overline{0} \\
\bar{d} \\
z\end{array}$ & 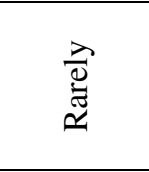 & 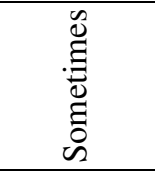 & $\underbrace{\stackrel{\Xi}{0}}_{0}$ & $\sum_{\substack{\pi \\
\pi}}^{\infty}$ & $\begin{array}{c}\text { Total } \\
\text { score of } \\
\text { the item }\end{array}$ & \\
\hline \multirow{2}{*}{ Teacher-made tests } & $75 \backslash 75$ & $19 \backslash 19$ & $8 \backslash 18$ & $25 \backslash 11$ & $12 \backslash 14$ & $11 \backslash 13$ & \multirow{2}{*}{$-213 \backslash 209$} & \multirow{2}{*}{$.048 *$} \\
\hline & $\%$ & $25.3 \backslash 25.3$ & $10.7 \backslash 24$ & $33.3 \backslash 14.7$ & $16 \backslash 18.7$ & $14.7 \backslash 17.3$ & & \\
\hline \multirow{2}{*}{ Editing } & 56156 & $9 \backslash 14$ & $3 \backslash 13$ & $16 \backslash 6$ & $17 \backslash 6$ & $11 \backslash 17$ & \multirow{2}{*}{$-186 \backslash 167$} & \multirow{2}{*}{$.001 *$} \\
\hline & $\%$ & $16.1 \backslash 25$ & $5.4 \backslash 23.2$ & $28.6 \backslash 10.7$ & $30.4 \backslash 10.7$ & $19.6 \backslash 30.4$ & & \\
\hline \multirow{2}{*}{ Sentence completion items } & $56 \backslash 56$ & $16 \backslash 19$ & $3 \backslash 9$ & $12 \backslash 6$ & $14 \backslash 11$ & $11 \backslash 11$ & \multirow{2}{*}{$-169 \backslash 154$} & \multirow{2}{*}{.230} \\
\hline & $\%$ & $28.6 \backslash 33.9$ & $5.4 \backslash 16.1$ & $21.4 \backslash 10.7$ & $25 \backslash 19.6$ & $19.6 \backslash 19.6$ & & \\
\hline \multirow{2}{*}{ Short answer items } & 56156 & $15 \backslash 20$ & $4 \backslash 7$ & $14 \backslash 9$ & $13 \backslash 9$ & $10 \backslash 11$ & \multirow{2}{*}{$-167 \backslash 152$} & \multirow{2}{*}{.360} \\
\hline & $\%$ & $26.7 \backslash 35.7$ & $7.14 \backslash 12.5$ & $25 \backslash 16.07$ & $23.2 \backslash 16.1$ & $17.8 \backslash 19.6$ & & \\
\hline \multirow{2}{*}{$\begin{array}{l}\text { Multiple-choice items to identify } \\
\text { grammatical errors }\end{array}$} & 56156 & $16 \backslash 29$ & $7 \backslash 8$ & $11 \backslash 4$ & $11 \backslash 8$ & $11 \backslash 7$ & \multirow{2}{*}{$-162 \backslash 124$} & \multirow{2}{*}{.076} \\
\hline & $\%$ & $28.6 \backslash 51.8$ & $12.5 \backslash 14.3$ & 19.617 .1 & $19.6 \backslash 14.3$ & $19.6 \backslash 12.5$ & & \\
\hline \multirow{2}{*}{ Matching items } & $56 \backslash 56$ & $44 \backslash 35$ & $2 \backslash 3$ & $3 \backslash 5$ & 418 & $3 \backslash 5$ & \multirow{2}{*}{$88 \backslash 113$} & \multirow{2}{*}{.469} \\
\hline & $\%$ & $78.6 \backslash 62.5$ & $3.6 \backslash 5.4$ & $5.4 \backslash 8.9$ & $7.1 \backslash 14.3$ & $5.4 \backslash 8.9$ & & \\
\hline \multirow{2}{*}{ true-false items } & $56 \backslash 56$ & $47 \backslash 44$ & $2 \backslash 2$ & $2 \backslash 2$ & $1 \backslash 4$ & $4 \backslash 4$ & \multirow{2}{*}{$81 \backslash 90$} & \multirow{2}{*}{.754} \\
\hline & $\%$ & $83.9 \backslash 78.6$ & 3.613 .6 & 3.613 .6 & $1.8 \backslash 7.1$ & $7.1 \backslash 7.1$ & & \\
\hline
\end{tabular}

Note. ${ }^{*} p<0.05$

\section{Table 10}

Frequency of standardized writing tests

\begin{tabular}{|c|c|c|c|c|c|c|c|c|}
\hline \multirow{2}{*}{\multicolumn{2}{|c|}{$\begin{array}{c}\text { Standardized writing } \\
\text { tests }\end{array}$}} & \multicolumn{6}{|c|}{ adultslyoung adults' teachers } & \multirow[b]{2}{*}{$\begin{array}{l}\dot{\infty} \\
\dot{n} \\
\dot{0} \\
\text { 命 }\end{array}$} \\
\hline & & $\begin{array}{l}\dot{\bar{\Delta}} \\
\dot{0}\end{array}$ & 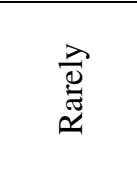 & 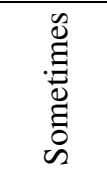 & 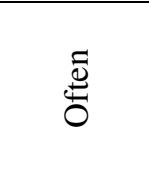 & $\sum_{i}^{\infty}$ & $\begin{array}{c}\text { Total } \\
\text { score of } \\
\text { the item }\end{array}$ & \\
\hline \multirow{2}{*}{$\begin{array}{l}\text { Standardized } \\
\text { writing tests }\end{array}$} & $\mathrm{N}$ & 26129 & $17 \backslash 7$ & $15 \backslash 7$ & $11 \backslash 14$ & $6 \backslash 18$ & \multirow{2}{*}{$179 \backslash 210$} & \multirow{2}{*}{$.009 *$} \\
\hline & $\%$ & $34.7 \backslash 38.7$ & $22.7 \backslash 9.3$ & $20 \backslash 9.3$ & $14.7 \backslash 18.7$ & 8124 & & \\
\hline
\end{tabular}

Note. No. of teachers in each group: $75 ;{ }^{*} p<0.05$

\subsection{Differences in the methods used by teachers of two groups}

The researcher found significant differences in the methods of assessing writing used by teachers in adult and young adult EFL classes. Chi-square test showed that teachers of young adult learners were significantly more inclined to use dictation and standardized writing tests than teachers of adult learners. Instead, teachers of adult learners made use of written summaries, portfolios, editing, and teacher-made tests significantly more than teachers of young adult learners.

\section{Discussion and conclusion}

The present study aimed at investigating different methods of assessing writing used by teachers of adult and young adult learners in Iran and also compared the frequency of these methods in two groups.

It was found that the most frequent methods among teachers of adult and young adult learners were writing essays and dictation respectively. Teachers of young adult learners reported that they used dictation considerably 
Ketabi, S.

more than teachers of adult learners. As for editing, portfolios, and preparing summaries of what is read, the researcher found that teachers of adult learners employed them significantly more than teachers of young adults. Alternative assessment tasks of portfolios, journals, and self/peer-assessment were the least common methods used by teachers of both groups. As a matter of fact, most of them reported that they never or rarely made use of these methods. This finding is a paradox by considering the results found by many researchers in Iran who showed that alternative assessment methods are beneficial in improving students' proficiency in writing (Elahinia, 2004; Nezakatgoo, 2005; Javaherbakhsh, 2010; Ghorchaei, Tavakoli, and Nejad Ansari, 2010; Moradan \& Hedayati, 2011; Sharifi \& Hassaskhah, 2011; Mosmery \& Barzegar, 2015).

Unpopularity of portfolios and journals can be discussed based on the fact that these methods need considerable amount of time to be effectively conducted. As Brown (2004) indicated, alternative assessment methods are not always practical. Table 11 shows the status of different alternative assessment methods.

\section{Table 11}

Principled evaluation of alternatives in assessment

\begin{tabular}{lcccccc}
\hline Principle & Portfolio & Journal & Conference & Interview & Observation & Self/peer \\
\hline Practicality & low & low & low & mod & mod & mod \\
Reliability & mod & mod & low & mod & mod & low \\
Face validity & high & mod & high & high & high & mod \\
Content validity & high & high & high & high & high & high \\
Washback & high & high & high & mod & mod & high \\
Authenticity & high & high & high & mod & high & high \\
\hline
\end{tabular}

Source: Brown (2004), p. 278

As can be seen, practicality of alternative assessment methods is not high. Self- and peer-assessment are moderately practical, but they have low reliability because of variation within and across learners (Brown, 2004). It might be a reason of why teachers did not trust self- or peer-assessment in this study.

Moreover, it was seen that teachers did not have adequate knowledge of portfolios and journals. In fact, when the researcher was distributing the questionnaires, the most frequent question she answered was "what are journals and portfolios?" Teachers cannot employ these two methods of alternative assessment because they do not truly know what they are. Therefore, lack of knowledge about alternative assessment methods and insufficient amount of time can be possible reasons for unpopularity of portfolios, journals, and peer/self-assessment among Iranian teachers.

When the results were compared with those found in Cheng et al.'s (2004) study, the researcher concluded that Iranian teachers did not use a variety of methods to assess writing. They relied on imitative, responsive, and extensive tasks and completely forgot about alternative methods of assessment. It should be discussed whether negligence in using alternative assessment has any destructive effect on building students' writing skill. As Brown (2004) stated, all methods could be beneficial, but using one method instead of a variety of methods could not help in building students' proficiency.

Comparing the results with the findings in Cheng et al.'s (2004) study also indicated that writing essays was reported to be popular among teachers in Beijing, Hong Kong, and Canada. Unpopularity of using journals as a method to assess writing was also observed among teachers of Hong Kong. In addition, teachers in Beijing did not employ portfolios very much.

An option in the questionnaire asked about the frequency of teacher-made paper-and-pencil tests. It should be said that this method was not popular among teachers as less than half of them in both groups reported that they always or often made use of their own tests. Teachers of adult learners, however, were significantly more interested in using this method than teachers of young adult learners. In order to assess writing, teachers of both groups preferred to choose editing as the most common format of items. Sentence completion and multiple choice items were other common items among Iranian teachers of adult and young adult learners. Moreover, it can be said that teachers in Hong Kong were not interested in using their own tests, as were teachers in Iran. Editing was also the most common item among teachers in Hong Kong, Canada, and Beijing. 
The percentage of Iranian teachers of adult learners who employed standardized tests is like teachers in Canada. Teachers in Hong Kong had the least percentage and teachers in Beijing were the most interested teachers in using standardized tests.

\section{References}

Brown, H. D. (2004). Language assessment: principles and classroom practices. New York: Pearson Education.

Brown, J. D., \& Hudson, T. (1998). The alternatives in language assessment. TESOL Quarterly, 32, 653-675. http://dx.doi.org/10.2307/3587999

Cheng, L., Rogers, T., \& Hu, H. (2004). ESL/EFL instructors' classroom assessment practices: purposes, methods, and procedures. Language Testing, 21(3), 360-389. http://dx.doi.org/10.1191/0265532204lt2880a

Elahinia, H. (2004). Assessment of writing through portfolios and achievement tests. Unpublished Masteral thesis, Teacher Training University, Iran.

Genesee, F., \& Upsher, J. A. (1996).Classroom-based evaluation in second language education. Cambridge: Cambridge University Press.

Ghoorchaei, B., Tavakoli, M., \& Nejad Ansari, D. (2010). The impact of portfolios assessment on Iranian EFL students' essay writing: A process- oriented approach. Journal of Language Studies, 10, 35-51.

Grabowski, J. (1996). Writing and speaking: Common ground and differences toward a regulation theory of written language production. In C. M. Levy \& S. Ransdell (Eds.), The science of writing (pp. 1-27). New Jersey: Lawrence Erlbaum Associates.

Hamp-Lyons, L., \& Kroll, B. (1997). TOEFL 2000 - writing: Composition, community, and assessment. New Jersey: Educational Testing Service.

Harris, M., \& McCann, P. (1994). Assessment (Handbook for the English classroom). Oxford: Heinemann Publishers.

Javaherbakhsh, M. R. (2010). The impact of self-assessment on Iranian EFL learners' writing skill. English Language Teaching, 3(2), 213-218. http://dx.doi.org/10.5539/elt.v3n2p213

Kroll, B. (1990). Considerations for Teaching an ESL/EFL Writing Course. In Celce-Murcia, M. (Ed.). (2001). Teaching English as a second or foreign language (3rd ed., pp. 219-232). New York: Heinle \& Heinle.

Moradan, A., \& Hedayati, N. (2011). The impact of portfolios and conferencing on Iranian EFL writing skill. Journal of English Language Teaching and Learning, 8, 115-141.

Mosmery, P., \& Barzegar, R. (2015). The effects of using peer, self, and teacher-assessment on Iranian EFL learners' writing ability at three levels of task complexity. International Journal of Research Studies in Language Learning, 4(4), 15-27. http://dx.doi.org/10.5861/ijrsll.2015.928

Nezakatgoo, B. (2005). The effects of writing and portfolio on final examination scores and mastering mechanics of writing of EFL students. Unpublished Masteral thesis, Allame Tabtba'i University, Tehran, Iran.

Reppen, R. (2002). The genre-based approach to content writing instruction. In J. C. Richards \& W. A. Renandya (Eds.), Methodology in language teaching: An anthology of current practice (pp. 321-327). Cambridge: Cambridge University Press. http://dx.doi.org/10.1017/CBO9780511667190.045

Sharifi, A., \& Hassaskhah, J. (2011). The role of portfolios assessment and reflection on process writing. Retrieved from http://www.asian-efl-journal.com/PDF/March-2011.pdf

Weigle, S. C. (2002). Assessing writing. Cambridge: Cambridge University Press. http://dx.doi.org/10.1017/CBO9780511732997 
Ketabi, S. 